\title{
Physical Conditions of Swimming Athlete
}

\author{
Yendrizal $^{1 *}$ and Gusdi Wardiman ${ }^{2}$ \\ ${ }^{1,2}$ Dep. of Coaching,Faculty of Sport Science, Universitas Negeri Padang, Padang, Indonesia \\ *Corresponding author. Email: yendrizal@fik.unp.ac.id
}

\begin{abstract}
The problem of this research is the low achievement of swimming athletes. This study aims to determine the level of physical condition of swimming athlete. The research design used is descriptive research. The population was swimmers of Golden Black Swimming Club, amounting to as many as 30 people. The sampling technique was purposive sampling, so the number of samples in this study were 7 athletes. Instrument in this study were 1) sprint test 50 meters for measuring speed.2) Pull -up test for measuring arm muscle strength endurance 3) standing broad jump test for measuring leg muscle explosive power. Mechanical analyst of the data is using descriptive statistics percentage. The results of the study are: (1) The level of the ability of the speed of swimming athletes is at a moderate level with an average acquisition of 8.0 seconds. (2) The level of ability of adhesion of the athlete's arm muscle strength is at a level less with an average ability gain of 5.29 times the repetition. ( 3 ) The level of explosive ability of athlete's leg muscle is at a very low level with the acquisition of an average ability of $192,43 \mathrm{~cm}$.
\end{abstract}

Keywords: physical condition, swimming athlete

\section{INTRODUCTION}

The achievement of the athletes of the Golden Black Lotus Club in Padang has not been maximized yet, the researchers suspect are caused by several physical conditions including the leg muscle power used at the start. At the start of the average Golden Black, Club athletes are often not perfect one of them is not far jump. Usually, if you lose from start to finish the athlete will lose

Base on the discussion of the problem described above, it can be formulated of the problem in this research are:

1. What is the endurance level of 50 meter freestyle swimming?

2. What is the level of strength of the 50-meter freestyle swimming armored athlete?

3. How do the limbs of the 50-meter freestyle swim athlete swim?

Thomas (2006) says "Pool members are fun, relaxation, challenges, competition and struggle to save lives in emergencies in water". Based on the theory sports pool has a variety of benefits every man, with swimming can give pleasure for someone, because with swimming people will feel the relaxation.Swimming is one of the branches of sports which played individuals or groups.

Swimming does not determine a pattern of hand or foot movements that must be performed. Swimming can use hand or foot movements, so it can float and move from one place to another. The most popular swimming style according to Thomas (2006:): "the sloping force is the most powerful force, therefore rescuers use it to save people who are drowning. Freestyle is the fastest and most efficient style. Elementary backstroke is the easiest and safest way to save energy, and breaststroke is a style of resting, which allows you to hold your head above the water surface, to see the direction you are going and even to talk with your swimming partner ".

The term "physical condition" refers to Irawadi (201 1): "a combination of the words condition and physical. In KBBI the word condition is defined as a state, while physical means body and body. If interpreted in literature physical condition will mean the state of the body ". The ability of physical conditions is a basic ability to develop other sports achievement abilities. The purpose of fostering physical conditions is to enhance physical development in general and enhance specific physical development that perfects the techniques of the sport chosen or fostered, the purpose of fostering physical conditions depends on the condition or skills of a person to improve the biometric abilities needed to increase the achievements of the branch sport. Heri (2009) said, "swimming is an element of its own physical condition so that it requires more precise physical development, elements of physical condition needed in swimming include Explosive Power, Strength, Speed, Determination, Coordination, and Flexibility". Besides the physical condition that is needed in swimming is speed. High and low ability athlete's swimming style is influenced 
by speed because swimming is included in sports that use a lot of energy.

According to Kirkenda II, Gruber and Johnson (1980), velocity is defined as distance per unit time, i.e. velocity is measured in units divided by units of time. Men sequence in Arsil Corbin (2012) "speed is the ability to move from one place to other in the shortest time".

According to Irawadi (2011) "Strength ( strength) is defined as the ability to use force in the form of lifting or holding a load". According to the pump in Irawadi (2011), "defines strength as the ability of muscles and nerves to cope with internal and external loads". The picture of strength will be seen when someone tries to lift or hold a burden on an activity.

According to Annarino (1976) in Arsill ( 2008 ), explosive power is related to the strength and speed of dynamic and explosive muscle contraction and involves the expenditure of maximum muscle strength in a short duration of time.

According to Irawadi (2011) "defines the leg muscle explosive power of a person's ability to move the body or its parts in a strong and high speed. Meanwhile according to Hatfield in Ismaryati (2006) " Power is the result of multiplication between force (force) and distance (distance) divided by time (time)".

In the achievement of swimming sports achievements physical conditions are needed, especially at the time of the match to get a good physical then it can be realized through systematic, planned, continuous, and improved training. As explained by Syafruddin (2011: 54): "Physical conditions are elements or basic abilities that must be possessed by every athlete to achieve a sporting achievement".

The power factor of leg muscle explosions in swimming is needed when doing start and reversal, the explosive power that is done must be fast and good in training and in competition. The faster and better an athlete's explosive power in a match, the easier the athlete wins. Waist is very dominant, needed at the start of swimming freestyle, butterfly style, breaststroke, and backstroke. If the waist is done well, the athlete can swim well in all branches that are contested.

Both physical conditions also require endurance in the sport of swimming matches. Swimming competitions consist of $50 \mathrm{~m}, 100 \mathrm{~m}, 200 \mathrm{~m}$, and 400 $\mathrm{m}$. Thus endurance athletes are demanded during the game from the beginning to the final round.

From the basic components of physical conditions, it is necessary to get training in accordance with their respective portions, because these components have differences in energy systems, forms of movement, training methods and training load used in various sporting activities (fox) in Asril (2008: 5 ).

The achievement of the athletes of the Golden Black Lotus Club in Padang has not been maximized yet, the researchers suspect are caused by several physical conditions including the leg muscle power used at the start. At the start of the average Golden Black Club athletes are often not perfect one of them is not far jump. Usually, if you lose from start to finish the athlete will lose.

\section{RESEARCH METHODS}

This research is a descriptive study that aims to obtain information about the current situation and see the relationship between the variables that exist. The study was conducted in June 2019. The research site was conducted in the Taratai Padang swimming pool. The population of this study was swimmer Golden Lotus Black Padang Padang which totaled 30 vote, with details Age Group (KU) KU I my IV Sampling using technique purposive sampling, where researchers are determined for sampling. Researchers only used the sample in this study taken at the age group which amounted to the consideration of the physical condition of men and women. The sample in this study determined only the Golden Black Padang Club swimming athletes age group I (1 $3-14$ years) only for men, amounting to 7 people. The instruments used in this study were: 1) Speed test using sprints, 2) Arm Muscle Endurance Test by Using $P u$ - ups, 3) Explosive power Test by Using Standing Broad Jump. Data collection techniques in this study is to test the ability of physical conditions that are often used nationally by the PRSI (Indonesian Swimming Association). This test was conducted on swimming athletes who were sampled in the study, namely a test to measure endurance speed, endurance forearm, and Explosive Power. After the results of the data collected in the field, data processing is carried out, based on the data collected and has fulfilled the requirements for analysis. Data analysis techniques are performed using descriptive methods that use frequency and average tabulations ( descriptive percentages).

\section{RESULTS AND DISCUSSION}

\section{Speed of the Golden Lotus Lotus Black Swimming Club Athlete}

The research question posed is: what is the level of ability of the Golden Black Swimming Club Padang Swimming athlete's speed? 
Table 1. Speed Data Distribution of Golden Black Swimming Club Padang Athletes speed data.

\begin{tabular}{|c|c|c|c|}
\hline \multirow{2}{*}{$\begin{array}{c}\text { Interval Class } \\
(\text { seconds })\end{array}$} & \multicolumn{2}{|c|}{ Frequency } & \multirow{2}{*}{ Classification } \\
\cline { 2 - 3 } & Absolute $(\mathrm{Fa})$ & Relative $(\%)$ & \\
\hline SD-6.7 seconds & 0 & $0.0 \%$ & Very well \\
\hline $6.8-7.6$ seconds & 2 & $28.6 \%$ & Well \\
\hline $7.7-8.7$ seconds & 5 & $71.4 \%$ & S edang \\
\hline $8.8-10.3$ seconds & 0 & $0.0 \%$ & K urang \\
\hline $10,4-$ etc & 0 & $0.0 \%$ & Very lacking \\
\hline Total & 7 & $100.0 \%$ & \\
\hline
\end{tabular}

Of the seven people sample, so as much as 2 people $(28.6 \%)$ had a rate of speed capabilities clasifiaksi Wheather acquisition score ranges of 6.8 - 7.6 seconds. 5 people $(71,4 \%)$ had a rate of speed capabilities clasifiaksi being with the acquisition of scores ranging between a 7.7 -
8.7 seconds. And for excellent, less and less complete clarification $(0 \%)$. To more clearly understand the spread of data (data distribution) the speed of the Golden Black Swimming Club Padang athletes, it can be understood through the stem histogram as follows.

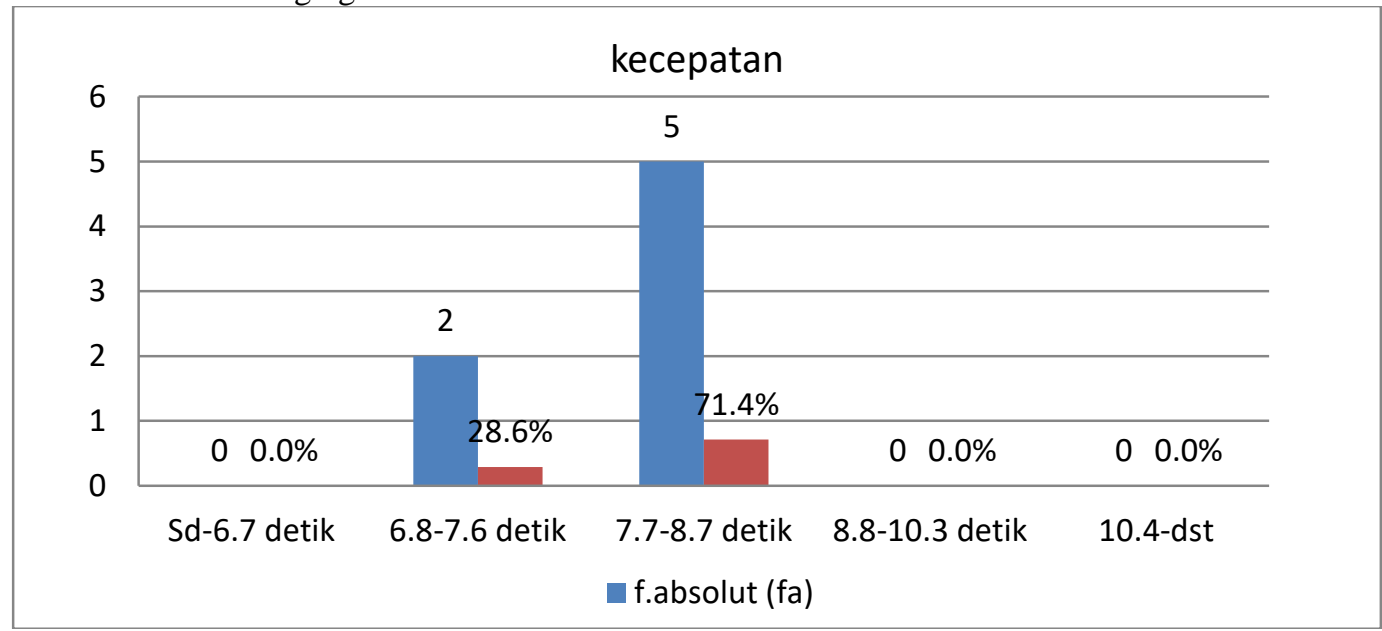

Graph 1. Golden Black Swimming Club Padang City athlete speed data

2. Arm Muscle Strength Endurance Athletes Pool Golden Black Swimming Club Padang Table 2. Distribution of Data Frequency on Dayatahan Muscle Strength of Athlete's Golden Black Swimming Club Padang.

\begin{tabular}{|c|c|c|c|}
\hline \multirow{2}{*}{$\begin{array}{c}\text { Interval Class } \\
\text { (Number of Movements) }\end{array}$} & \multicolumn{2}{|c|}{ Frequency } & \multirow{2}{*}{ Classification } \\
\cline { 2 - 3 } & Absolute $(\mathrm{Fa})$ & Relative $(\%)$ & \\
\hline$>16$ & 0 & $0.0 \%$ & Very well \\
\hline $11-15$ & 0 & $0.0 \%$ & Well \\
\hline $6-10$ & 3 & $42.9 \%$ & S edang \\
\hline $2-5$ & 4 & $57.1 \%$ & K urang \\
\hline $0-1$ & 0 & $0.0 \%$ & Very lacking \\
\hline Total & 7 & $100.0 \%$ & \\
\hline
\end{tabular}

Of the seven people sample, so as many as three people $(42.9 \%)$ had levels of ability endurance arm muscle strength clasifiaksi meanwhile with acquisition scores ranged from $6-10$ repetitions. $4(57,1 \%)$ had levels of ability endurance arm muscle strength klasifiaksi less with the acquisition of scores 
ranging from 2 - 5 times repetition. To more clearly understand the data distribution (distribution of data) of the strength of the arm muscle strength of the Golden
Black Swimming Club Padang athlete, it can be understood through the stem histogram as follows.

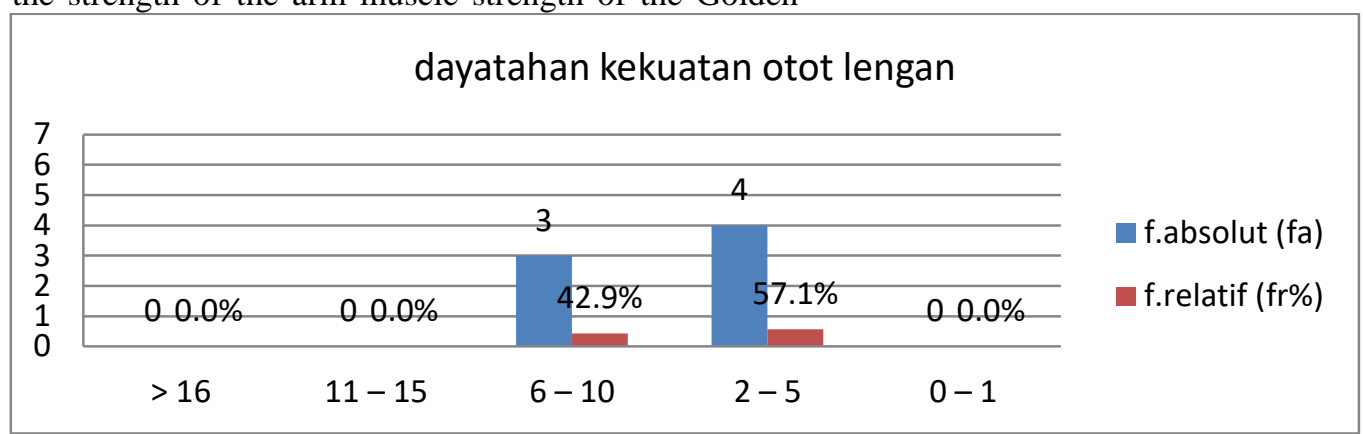

Graph 2. Data on the Strength of Muscle Strength of the Athlete's Golden Black Swimming Club in Padang

\section{Explosion Power of the Limbs of the Athlete Swimming Pool Golden Black Swimming Club Lotus City of Padang}

Table 3. Frequency Distribution of Muscle Explosion Data of Athlete's Golden Black Swimming Club in Padang City

\begin{tabular}{|c|c|c|c|}
\hline \multirow{2}{*}{$\begin{array}{c}\text { Interval Class } \\
(\mathrm{cm})\end{array}$} & \multicolumn{2}{|c|}{ Frequency } & \multirow{2}{*}{ Classification } \\
\cline { 2 - 3 } & Absolute $(\mathrm{Fa})$ & Relative $(\%)$ & \\
\hline$>250$ & 0 & $0.0 \%$ & Perfect \\
\hline $241-250$ & 0 & $0.0 \%$ & Very good \\
\hline $231-240$ & 0 & $0.0 \%$ & Well \\
\hline $221-230$ & 1 & $14.3 \%$ & Is \\
\hline $211-220$ & 2 & $28.6 \%$ & Less \\
\hline$<210$ & 4 & $57.1 \%$ & Very lacking \\
\hline Total & 7 & $100.0 \%$ & \\
\hline
\end{tabular}

Of the seven people sample than 4 people $(57,1 \%)$ have the ability explosive muscular limbs in the very lacking classification with the acquisition score of less then $210 \mathrm{~cm} .2$ people $(28.6 \%$ ) had leg muscle explosive ability, including less classification, with scores ranging from 211 to $220 \mathrm{~cm} .1$ person $(14.3 \%)$ has the ability of leg muscle explosive power including moderate classification with acquisition values ranging from $221-230 \mathrm{~cm}$. While athletes who have the ability of leg muscle explosive power in the perfect classification $(>250 \mathrm{~cm})$, very good classification ( 241-250) and in well classification ( 231-240 ) no (\%). To more clearly understand the data distribution (data distribution) of the leg muscle explosive power of the Golden Black Swimming Club Padang athlete, it can be understood through the stem histogram as follows

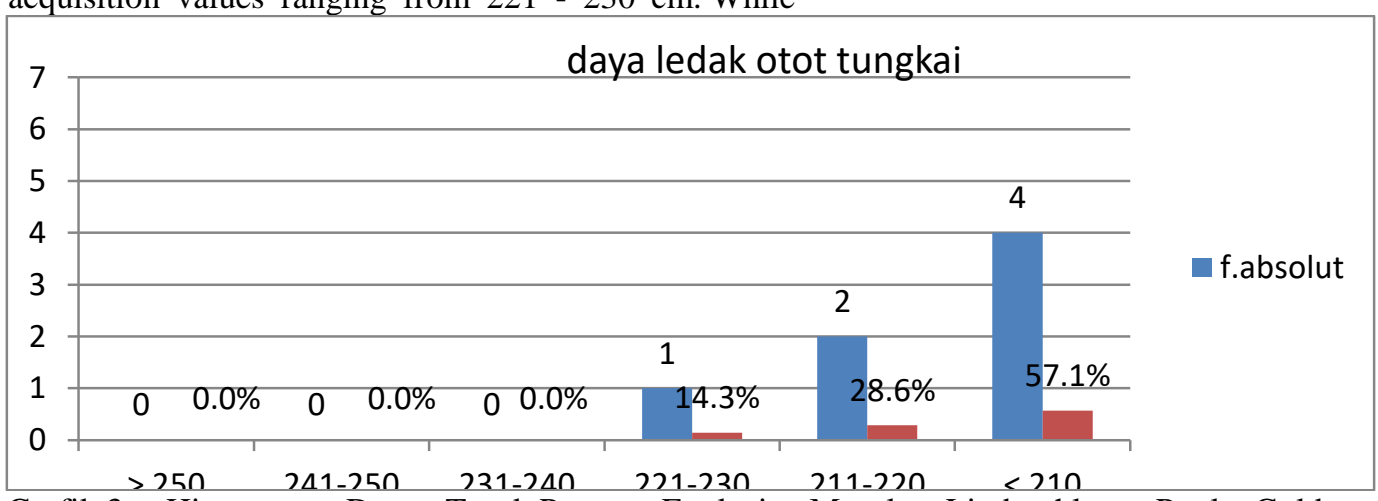

Grafik 3. Histogram Data Trunk Power Explosive Muscle Limb athlete Pool Golden Black Swimming Club Kota Padang 


\section{The speed of the Golden Black Swimming club Lotus Sport Athlete in the City of Padang}

Based on the results of a speed test using a 50meter sprint, an average of 8.0 seconds was obtained. If the number is consulted into the assessment norm, the score falls into the medium category. Thus it can be concluded that the speed condition of the Golden Black Swimming Club Lotus Sport of the Padang City athletes is currently in the medium category. Therefore, the results of this study can be information material for evaluating the next athlete's training for the trainer so as to improve the speed conditions the athlete goes through a proper and measurable training program at the prime level (excellent).

According to Corbin in Asril (2012: 82), "speed is theability to move from one place to another in the shortest time possible".

In connection with this can be known the ability of speed in the 50-meter freestyle swimming is very necessary because if the speed is good then the athlete will easily get the desired achievement.

\section{Dayatahan Muscle Strength of the Golden Black Swimming Athletes of the City of Padang}

Based on the results of the test on the strength of the muscular strength of the Padang City Golden Black Lotus Club Athletes Swimming Arm using pull-ups. an average of 5.29 repetitions was obtained. If the number is consulted into the assessment norms, the score falls into the less category. Seeing this, the Golden Black Swimming Club Lotus City Padang coach was suggested to be able to increase the strength of the arm muscle strength at a more excellent level (excellent).

With the results of the research obtained, the Golden Black Swimming Club Lotus City Padang swimming coach so that these findings can be an evaluation in preparing physical exercise programs in the future. A swimming athlete must have the strength condition of the arm muscle strength in a very good classification. This is due to the fact that the strength of the arm muscle strength is a physical ability needed by the arm for activities carried out repeatedly in a relatively long time. When swimming activity takes place it can be seen that there is strongarm movement and it is repeated repeatedly during the activity. The ability of a swimmer to maintain the frequency of arm movements from fatigue is influenced by the strength of his arm muscles.

Arm movements in swimming activities are movements that can produce thrust that can encourage the body to slide in the water. The greater the thrust generated by the arm's motion, the greater the sliding speed produced. As long as a swimmer can move his arm properly and correctly so long as the force of thrust can be generated and the body can continue to slide. To produce a large thrust during swimming activity takes place it requires endurance and strength of the arm to move. Therefore, swimmers must have good resistance to arm muscle strength. Opinion of Irawadi (2017: 129) "The real form of the strength of the arm muscle strength is the ability of the athlete's arm to work which requires strength in a relatively long time".

Seeing the results of existing research, the swimming coach and coach of the Golden Black Swimming Lotus Club of Padang City to respond to these findings. Bearing in mind the importance of the function of the strength of the arm muscle strength, the trainer must evaluate and innovate the physical condition training going forward. The trainer must be able to make training program exercises the strength of the arm muscles with a variety of forms of exercise through physical training. This step must be done because physical condition is one of the factors of achievement factors

\section{The explosive power of the limbs of the Golden} Black Swimming Club Lotus City Athlete

Based on the results of the explosive power of the limbs of the Golden Black Swimming Club Lotus City Athlete Swimming Pool using standing broad jump . an average yield of $192.43 \mathrm{~cm}$ was obtained. If the number is interpreted into the standing broad jump test norms, the number indicates that the ability of leg muscle explosive power is in the classification of very little.

Opinions of Sismadiyanto and Ermawan (2008) "According to some swimming experts, the comparison of the results of the pushes of the legs and the pull of the arms will be compared to 80:20 percent". Based on this opinion it can be understood that the leg movements must be mastered well. Not only limited to the mastery of motion, but the movement of the limbs must be done forcefully and quickly to produce a large driving force towards the body. Therefore, to produce a large thrust force, each time the leg movements must be performed with strong and fast movements (explosive).

The function of leg muscle explosive power in addition to supporting leg movement when swimming, it is also useful to produce jumps at start. Syafruddin's opinion (2011) "says that Explosive power is much needed in sports or in techniques from sports that require leaps". Zimmermann's opinion in Irawadi (2014) said: "Explosive power is the ability to move the body or body parts powerfully at high speed". In connection with this branch of sports, swimming really requires the ability of leg muscle explosive power. The higher the explosive power an athlete has jumping at the time of 
the star, the better the results will be in achieving the expected achievements.

\section{CONCLUSIONS AND SUGGESTIONS}

\section{A. Conclusions}

Based on the results of the data analysis, several conclusions can be obtained as follows: 1) The level of ability The speed of athletes in the Golden Black Swimming Club of the Lotus City of Padang City is at the level of category enough with an average ability acquisition of 8.0 seconds. Therefore, the level of speed must be increased again. 2) The level of endurance ability of the muscular strength of the arm athletes of the Golden Black Swimming Club of the Lotus City of Padang is in the category level of less with an average ability gain of 5,29 times repetition. Therefore, the level of strength in the strength of the arm muscles must be increased again. 3) The degree of leg muscle explosive power swimmer Golden Black Swimming ClubTeratai Padang is located at the category level is less so with the acquisition of the ability of the average $192,43 \mathrm{~cm}$. then because of that, the level of training of the limbs of the Golden Black Swimming Club of the Lotus City of Padang City swimmers should be improved at the right level.

\section{REFERENCES}

[1] Arsil.2008. Pembinaan Kondisi Fisik. Padang: FIK UNP.

[2] Fox, E.L, Bowers, RW. Foss, ML. 1992. Sports Physiology. Philadelphia: WB. Sounders Company.

[3] Irawadi, Hendri. 2011. Kondisi Fisik dan Pengukurannya .Padang: FIK UNP.

[4] Jhonson, L. Barry \& Nelson j. (1986). Pratikal Measurement For Evaluation Physical. New York: Milar publishing company.

[5] Thomas, David G. Tanpa Tahun. Renang. Tingkat Pemula.Terjemahan oleh Alfons Palangkarya. 2006. Jakarta: PT. Rajagrafindo Persada. 